Ann. Génét. Sél. anim., I976, 8 (4), 537-540.

NOTE

\title{
ERYTHROCYTE OSMOTIC RESPONSE TEST ON MALIGNANT HYPERTHERMIA-SUSCEPTIBLE PIGS
}

\author{
W. A. KING *, L. OLLIVIER **, and Parvathi K. BASRUR ***
}

with the technical collaboration of Mrs Marie-Reine LANGLors

* Department of Animal Genetics, Nutrition and Hygiene, Royal Veterinary College, S-750 07 Uppsala 7, Sweden

** I. N. R. A., Station de Génétique quantitative et appliquée, Centre national de Recherches zootechniques, 78350 Jouy-en-Josas, France

*** Department of Biomedical Sciences, University of Guelph, Ontario, Canada

\section{SUMMARY}

Erythrocytes harvested from a group of $\mathrm{I} 7$ young Belgian Landrace male pigs, of which ro were classified as malignant hyperthermia susceptible by exposure to halothane anesthetic and 7 were classified as non-susceptible, were exposed to osmotic shock in saline solutions at 0.9 percent, 0.8 percent and 0.7 percent. The results show an increased rate of hemolysis in susceptible pigs as compared to non-susceptible ones. This is in favour of the hypothesis of a membrane defect being at the origin of malignant hyperthermia, an abnormality which is generally associated with an increased muscular development.

Similar results obtained in cattle by KING et al (1976) indicate that the same defect occurs in so-called double-muscled animals.

Heavily muscled pigs which are exposed to stress in the form of physical exercise or to membrane depolarising agents including halothane often exhibit a response characteristic of Malignant Hyperthermia (MH) in man (HALL et al., Ig66). The clinical features of this stress induced syndrome include gross muscular rigidity, 
rapid rise in body temperature, accelerated pulse rate, hyperventilation, blotchy cyanosis, metabolic acidosis and rapid rise in the concentration of serum electrolytes (see CAMPION and TOPEL, I975 for review). In stress susceptible animals, the degenerative changes of the contractile elements and membrane components of the muscle fibers become wide-spread following the onset of the malignant hyperthermic reaction (VENABLE, I973).

It is generally agreed that Malignant Hyperthermia (MH) in pigs is determined by a single recessive gene with high penetrance. It has further been suggested that the same gene may be responsible for both heavy muscling and malignant hyperthermia (OLIIVIER, I968; OLLIVIER et al., I975).

A similar hereditary condition of stress susceptibility (double muscled syndrome) exists in heavily muscled cattle (HoLmes et al., I973). At the ultrastructural level this condition in cattle, is characterised by the degeneration of the contractile elements and membrane components of the muscle fibers. While the expression of these features varies between affected animals, the most consistent feature of this condition has been noted to be a generalized cell membrane defect. This membrane defect is thought to be responsible for the increased sensitivity of erythrocytes to osmotic shock observed in affected animals and carriers of this syndrome (KING and BASRUR, I974; KING et al., I976). Since the malignant hyperthermic pigs resemble the double muscled cattle in various important features, it is conceivable that the erythrocyte fragility is also shared by these two syndromes. In order to test the validity of this assumption, erythrocytes collected from a group of Belgian Landrace performance testing boars being used for halothane response test (at Le Transloy, Pas-de-Calais, France) were subjected to the erythrocyte osmotic response test.

Six milliliters of blood were drawn from the vena cava of each animal and transferred to a heparinized centrifuge tube. The animals were exposed to halothane treatment as described by OLIIVIER et al. (I975). Following exposure to halothane and subsequent identification of positive and negative reactors, the blood samples from Io negative and 7 positive animals were selected at random.

The blood samples were centrifuged, plasma was drawn off and the erythrocytes were washed three times in isotonic saline, using a Hettich Rotixa centrifuge and a Hettich Erylavit cell-washer. An aliquot of $0.5 \mathrm{ml}$ of packed $\mathrm{RBC}$ was rapidly added to each of three centrifuge tubes containing $2.5 \mathrm{ml}$ each of $0.9 \%, 0.8 \%$ and $0.7 \%$ of sodium chloride solution. The cells were suspended in these saline solutions and allowed to stand for 5 minutes prior to centrifuging the tubes at 3500 RPM for five minutes. Optical density (OD) of each supernatant solution was recorded at $540 \mathrm{~m} \mu$ with a PMQ II Zeiss Spectrophotometer and the percent hemolysis (OD in saline samples/OD in distilled water $\times$ Ioo) was calculated for each sample.

No significant difference in the rate of hemolysis was detected between the two groups in $0.9 \%$ saline. Significant differences $(\mathrm{P}<0.05)$ were found between the two groups in both 0.8 and $0.7 \%$ saline solutions (tabl. $\mathrm{I}$ ).

It is not surprising that there was no apparent difference in erythrocyte osmotic response in $0.9 \%$ saline within the short time ( 5 minutes) of exposure allowed in this test since the solution is near isotonic. 
The variability in the non-reacting group may be explained on the basis that these boars are likely to have been selected for conformation before entering the boar testing station. This group may include several carriers of MH.

The results seem to indicate that increased erythrocyte sensitivity to osmotic shock is a characteristic feature of Belgian Landrace pigs which react positively to halothane anesthetic. In a previous experiment on Landrace pigs of South Africa, HARRISON and VERBURG (I973) had noted an increased erythrocyte fragility. Our observation appears to be in keeping with the hypothesis that the primary defect in malignant hyperthermia is associated with the integrity of the muscle cell membrane. It has been hypothesized that the halothane response in pigs results from the defect of the sarcoplasmic reticulum which becomes impaired in its normal role of sequestering calcium (Summers, r973). As with the membrane defect in double muscled cattle, the membrane defect is not confined to the muscle cells.

TABIE I

\begin{tabular}{|c|c|c|c|}
\hline \multicolumn{4}{|c|}{$\begin{array}{c}\text { Mean Percentage Hemolysis in Various Concentrations of Saline } \\
\text { according to the type of reaction to halothane } \\
\text { Pourcentage moyen d'hémolyse à différentes concentrations salines } \\
\text { selon le type de véaction d̀ l'halothane }\end{array}$} \\
\hline \multirow{2}{*}{$\begin{array}{l}\text { Response } \\
\text { to halothane }\end{array}$} & \multicolumn{3}{|c|}{ Concentration of sodium chloride } \\
\hline & $0.9 \%$ & $0.8 \%$ & $0.7 \%$ \\
\hline Positive (10) .. & 15.40 & 46.73 & 83.58 \\
\hline Negative (7) .. & 3.52 & 16.33 & 55.78 \\
\hline F value $\ldots \ldots \ldots$ & 2.58 & 4.64 & 4.59 \\
\hline$P$ value $\ldots .$. & $<0.25$ & $<0.05$ & $<0.05$ \\
\hline Significance ....... & N.S. & $\mathrm{S}$ & $\mathrm{S}$ \\
\hline
\end{tabular}

Number in parenthesis indicates the number of animals in each group. NS : not significant; $\mathrm{S}$ : significant.

On the basis of these preliminary results it would appear that the erythrocyte fragility test is an efficient and relatively inexpensive means of detecting pigs affected with $\mathrm{MH}$ for the subsequent selection of heavily muscled animals. Since not all pigs recover from halothane treatment (around $8 \%$ mortality among positive reactors) the risk of death can be effectively reduced by using this method. Increasing the length of exposure to osmotic shock may provide a better separation of the two classes (affected and normal) and, possibly, the carriers from the overtly affected animals.

Reçu pour publication en novembre 1976.

\section{ACKNOWLEDGEMENTS}

We are grateful to Dr. J. J. Lauvergne, Génétique Factorielle, C. N. R. Z., Jouy-en-Josas, for his interest in this investigation and for the criticisms on this manuscript. This investigation was supported in part by a grant in aid of research by the National Research Council of Canada. 


\section{RÉSUMÉ \\ RÉPONSES OSMOTIQUES ERYTHROCYTAIRES DE PORCS SENSIBLES \\ A L'HYPERTHERMIE MALIGNE}

Les globules rouges de 17 jeunes verrats, de race Landrace Belge dont io étaient sensibles à l'hyperthermie maligne déclenchée par anesthésie à l'halothane et 7 ne l'étaient pas, ont été soumis à un choc osmotique dans des solutions salines à $0,9,0,8$ et 0,7 p. cent. Les résultats montrent un taux d'hémolyse significativement accru chez les individus sensibles, ce qui est en faveur de l'hypothèse d'un défaut de membrane à l'origine de cette anomalie, que l'on trouve généralement associée à un fort développement musculaire.

Des résultats similaires obtenus dans l'espèce bovine (KING et al., 1976) indiquent que le même défaut pourrait être à l'origine de l'hypertrophie musculaire caractéristique des bovins dits culards.

\section{REFERFNCFS}

Campion D. R., Topel D. G., I975. A review of the role of swine skeletal muscle in malignant hyperthermia. J. Anim. Sci., 41, 779-786.

Hall L. W., Woolf N., Bradley J. W. P., Jolly D. W., 1966. An unusual reaction to suxamethonium chloride. Brit. Med. J., 2, I305.

Harrison G. G., Verburg C., 1973. Erythrocyte osmotic fragility in hyperthermia-susceptible swine. Br. J. Anesth., 45, r3 $\mathrm{r}-\mathrm{r} 33$.

Holmes J. H. G., Ashmore C. R. and Robinson D. W., I973. Effect of stress on cattle with hereditary muscular hypertrophy. J. Anim. Sci., 36, 684-694.

KING W. A., BAsRUR Parwarthi K., 1974. Ultrastructural features of hereditary muscular hypertrophy in cattle. Can. J. Genet. Cytol., 16, 707.

King W. A., Baskur Parwathi K., Brown R. G., Berg R. T., I976. Osmotic response tests on erythrocytes for the detection of double muscle carriers in cattle. Ann. Génét. Sél. Anim., 8, 4I-45.

Ollivier L., Sellier P., Monin G., I975. Déterminisme génétique du syndrome d'hyperthermie maligne chez le porc de Piétrain. Ann. Génét. Sél. Anim., 7, 169-166.

Ollivier L., r968. Étude du déterminisme héréditaire de l'hypertrophie musculaire du porc de Piétrain. Ann. Zootech., 17, 393-407.

SUMmers R. J., 1973. Interaction between monoamine oxidase inhibitors and anaesthetics. In $\mathrm{R}$. A. Gordon, B. A. Britt and W. Kalow, ed., International Symposium on Malignant Hyperthermia. Charles C. Thomas, Springfield, Ill., 343-379.

Venable J. H., I973. Skeletal muscle structure in Poland China pigs suffering from malignant hyperthermia. In R. A. Gordon, B.A. Britt and W. Kalow, ed., International Symposium on Malignant Hyperthermia. Charles C. Thomas, Springfield, III., 208-223. 